\title{
Lithuanian Deterrence Strategy
}

The Lithuanian deterrence strategy is about making use of military threats to prevent other actors from taking particular actions. There are two major components that determine the success or failure of the Lithuanian deterrence strategy: the military's capabilities to carry out its threat against potential aggressors, and the will to do so. Special attention in this article will be given to the effectiveness of extended deterrence. It provides estimation on the sufficiency of Lithuanian capabilities to provide effective deterrence and recommends a potential direction for their use to strengthen deterrence. This article will discern current Lithuanian deterrence potential and possibilities to improve it using military, economic, as well as political means and other measures.

\section{Introduction}

Deterrence strategy defines how military power is used indirectly to achieve ones national security objectives. Deterrence is aimed to prevent unwanted actions from other countries or non state actors. The popularity of deterrence was influenced by the experiences brought from World War II, the demoralized conventional wisdom of traditional war and the advance of nuclear bombs that made defensive strategies obsolete. Deterrence became prominent since from the first glance it rejected the traditional notion of war and softened war fighting and killing elements embedded into the concept of military conflict. Quite cynically, deterrence strategy even allowed certain countries to proclaim that their policy is not directed against other nations and is of a purely defensive nature. This explains why in strategic documents of most countries, including Lithuania, the concept of deterrence occupies the central place and forms the basis for force structure development.

In Lithuania, the deterrence strategy was declared officially for the first time in the National Military Strategy approved by the State Defence Council in 2000 although its roots could be traced back to the concept of civil defence which was very popular in the first year after independence ${ }^{1}$. The latest version of the National Security Strategy and the National Military strategy declare deterrence as one of the main strategic principles ${ }^{2}$. The Lithuanian National Security Stra-

* Dr. Vaidotas Urbelis is a lecturer of the Institute of International Relations and Political Science of the University of Vilnius. Address: Vokiečiu 10, LT-2001 Vilnius, Lithuania, tel. +370 5 2785206, e-mail: vaidotasu@post.skynet.1t

${ }^{1}$ Lithuanian Military Defence Strategy, Vilnius: Leidybos centras prie KAM, 2000.

${ }^{2}$ Lithuanian National Security Strategy, Vilnius: KAM Leidybos ir informacinio aprūpinimo tarnyba, 2005; Lithuanian Military Strategy, Vilnius, KAM Leidybos ir informacinio aprūpinimo tarnyba, 2004. 
tegy of 2004 emphasises: “[Lithuanian deterrence strategy] relies upon the strengthening of the national defence system of the Republic of Lithuania and its military capabilities and on the principles of NATO's collective defence. A strong alliance is the most important factor of security of Lithuania, ensuring effective deterrence and in case of a direct threats a collective defence".

NATO Strategic Concept emphasises that the Alliance does not foresee a threat of conventional military attack against its member states. However in the future Lithuanian and their Allies' threat perceptions are subject to change. In the last decade threats to the world security, such as genocide or terrorism, came unexpectedly. Nobody can predict what awaits the world in next decades. The NATO intelligence community cannot provide Lithuanian military planners with the exact list of future threats let alone in the conventional military area. Ten year ago Poland in Lithuania was conceived as the major strategic opponent, now it is the main strategic friend and a close ally in NATO and the EU. No doubt that after ten years the Lithuanian threat perception will be completely different from the present. New challenges will come from non state actors or non-governmental organisations what will not be linked to any of the existing states. New threats could arise suddenly therefore the Lithuanian deterrence strategy must remain flexible and able to respond to different challenges of military and non-military nature.

Currently no country officially threatens Lithuania, although in neighbouring countries alarming tendencies can be noticed. The President of Belarus in public speeches frequently attacks NATO countries and organises military exercises within close proximity to Polish or Lithuanian borders. In most cases they coincide with elections and referendums in Belarus or NATO exercises in the neighbouring countries. For example in 2001 Belarus organised exercises Neman 2001. According to their scenario, which was leaked to the press, Belarusian forces repulsed a Lithuanian and Polish attack and together with Russian forces occupied part of the NATO territory. During the exercise Berezina 2002 Belarusian forces crossed Berezina and launched attacks westward. ${ }^{3}$ Most Belorussian exercises have a double agenda - peace operations for the public eyes and offensive military actions to demonstrate Belarusian and Russian military might and send strong political signals to NATO countries.

The development of the Lithuanian deterrence strategy could be divided into several important phases - before NATO membership and after it. Before 2004 Lithuania was seeking to deter its potential opponents, primary by using national assets. After becoming a member of NATO, the deterrence strategies of other NATO nations are extended to Lithuania. This article will present a comparison of both approaches to deterrence and highlight their weaknesses and strengths. This article will discern current Lithuanian deterrence potential and possibilities to improve it using military, economic, political and other measures. Special attention will be given to effectives of extended deterrence in Lithuania.

The methodology of such research suffers from several difficulties embed-

\footnotetext{
${ }^{3}$ Stratfor, "Russia: Hoping Military Exercises Speak Louder than Words to U.S." 2005 rugpjūčio $8 \mathrm{~d}$. http://www.stratfor.biz; Vaiceliunas A. "Lithuanian membership in NATO and the EU: a Secure Future", Canadian Forces College, 2004, http://198.231.69.12/papers/nssc6/ vaiceliunas.htm, 01062005.
} 
ded into the concept of deterrence. Military force in the modern world is primarily used for indirectly. For this reason calculations of events that have never happened are difficult. Furthermore information containing such data is often classified and not accessible to outside observers. Strategic documents and official speeches rarely reflect real understanding of threat perception and its evaluation. Military planning frequently does not match political interpretation of threats.

This article uses B. Buzan's and E. Herring's understanding of deterrence, which is defined as making of military threats to prevent another actor from taking particular action. The deterrence concept assumes that states and nonstate actors are at least semi-rational players that calculate the costs, risk, benefits, i.e. the behaviour that could be modified. Even terrorist organisations would fall into this category. Suicide bombers seem irrational from the first glance but they have clearly articulated objectives that are understandable from their perspective and normative system. All terrorist actions at the tactical level have at strategic level clearly formulated tasks and are understood as appropriate measure to achieve them.

Deterrence strategy encompasses retaliatory and defensive elements. Deterrence takes the assumption of rationality, in so far as the opponent is able to calculate or at least recognise relative costs and benefits. The determining factor for effective deterrence is whether the costs of the aggressor's action will outweigh the benefits that he could expect to gain. The costs of aggression may vary from military losses to economical damage. Cost may be incurred by Lithuania, by its Allies or by the international community. The benefits may vary from national pride to seizure of territory. Political leaders always include into this equation implications of aggressive action for internal stability and survival of the ruling regime.

There are two major components that determine the success or failure of the Lithuanian deterrence strategy: the military capabilities to carry out their threat against potential aggressor, and the will to do so. Lithuanian defence planners must decide what kind of capabilities Lithuania must create in order to incur unacceptable costs for would-be aggressor. The use of these capabilities requires a creative psychological strategy, involvement of political leaders and the whole society. This article will provide an estimation on the sufficiency of Lithuanian capabilities to provide effective deterrence and will recommend direction for their use to strengthen deterrence. The cost and benefits equation will provide the general framework for analysis.

\section{Military Capabilities - the Core of Effective Deterrence}

The ability to inflict costs using military and non-military means constitute the most important elements of the deterrence strategy. Lithuania can do it primarely using defensive means. A stout defence can fulfil the requirements of deterrence by displaying to potential enemies the huge costs needed to invade 
the country ${ }^{4}$. The deterrent can endorse this strategy by simply demonstrating or exercising his forces, but the promise to fight will be not credible unless he has real war fighting strategy ${ }^{5}$. The deterrer's objective is not simply to inform his opponents about his capabilities but impose the perception that he has the political will to fight hard and inflict costs upon the offender.

Strategists distinguish two main ways how unacceptable costs upon the aggressor may be imposed:

- To inflict punishment on the opponent in response to an attack and to retaliate against him with offensive strike towards his territory by destroying his major cities, administration and industrial facilities. In this case even information about such "ferocious" plans may persuade potential aggressor to abstain from military action. This strategy is defined as deterrence by retaliation ${ }^{6}$. Deterrence by retaliation requires a state to have enough strength to fight the enemy back without putting to much attention to defensive means.

- To fight and prevent an opponent from achieving its objectives - to hold and control state's territory. In this case the deterrer's task is to annihilate the opponent's forces and break his will to fight. Marginot line in France or Mannerhaim line in Finland were the primary examples of the strategy aimed at destroying opposing forces without carrying offensive actions into opponent's territory. This strategy is called deterrence by denial. In military terms denial and defence have virtually identical meanings ${ }^{7}$.

In theory Lithuania can impose costs to potential aggressor in both ways although deterrence by retaliation seems a less likely scenario. Such a strategy would require acquiring substantial capabilities to strike into the enemy's territory. Without weapons of mass destruction to implement such threats, for Lithuania it would be extremely difficult. Even conventional weapon systems that could be used for retaliation are outside the limits of the Lithuanian defence budget. The Lithuanian long term development plan approbed to the Parliament by the Ministry of Defence foresees no acquisition of long range artillery, ballistic or cruise missiles, bombers, fighter aircraft or ships. ${ }^{8}$ Current capabilities of the Lithuanian armed forces allow it to act successfully on the home territory and participate in crises response operations, but it is not able to retaliate in case of attack. Similar situations exist in Latvia and Estonia.

Baltic States can retaliate against potential aggressors only with non traditional means, e.g. organising acts of sabotage on the enemy's territory or using other asymmetrical measures. Lithuanian abilities to conduct information operations, disrupt enemy's chain of command, eliminate its leaders, and destroy lines of communication and computer networks may add to the effectiveness of

\footnotetext{
${ }^{4}$ Buzan B., Herring E., The Arms Dynamic in World Politics, London: LynneRieners, 1998, p.136. ${ }^{5}$ Osborne III G.K., The Nature of Deterrence. In J. Mearsheimer, ed., Conventional Deterrence, Toronto: Cornell University Press, 1985, p.10..

${ }^{6}$ Pierce A.C. The Strategic Defense Initiative: European Perspectives. In C. Kelleher, G.Mattox, ed., Evolving European Defense Policines, Lexington books, 1987, p.151.

7 Buzan B., Herring E., (note 5), p.135-136.

${ }^{8}$ National Defence System Long Term Development Plan, http://www.kam.lt, 15122005.
} 
deterrence. All these capabilities are important but potential aggressor would start considering them only if he knows about their existence. Revealing these capabilities would allow potential aggressor to adapt military plans accordingly and decrease their deterrent value of strong defence. After NATO membership Lithuania obtained new means of retaliation - military and non-military assets of her Allies. Their impact upon deterrence will be discussed in latter chapters.

Before membership in NATO, the effectiveness of Lithuanian deterrence strategy was based not only on rough military power, i.e. the ability of the armed forces to execute effective defence, but also on the determination of all citizens to put up unconditional and unlimited armed and unarmed resistance. A potential aggressor was made aware that upon attacking he would encounter not only resistance from the armed forces, but the total defence from the whole nation, and will suffer heavy losses disproportionate to the desired result. This strategy rested upon several assumptions. Lithuanian defence planners thought, that:

ful nations;

- Lithuanian is too small to win a conventional war against more power-

- Lithuanian armed forces although small in size could resist and constrain larger opponents for a certain period of time;

- Lithuanian population will resist aggressor by all available means and number of collaborators will be small;

- Resistance of civil population will last at least for a several years or maybe decades;

- Foreign countries will assist Lithuania by political, and maybe economic, but definitely not by military means;

These assumptions were incorporated into Lithuanian strategic documents and defence plans. The Lithuania Military Strategy of 2000 declares that Lithuanian deterrence strategy is based upon total and unconditional defence:

The essence of deterrence is defined by the concept that Lithuania will defend itself regardless of the nature of the aggression, the strength of the attacking forces and whether or not international assistance will be available. In case of an armed attack, Lithuania will prevent the adversary from achieving his goals - to effectively control the territory of the State, its infrastructure and resources, and establish an occupation regime $^{9}$.

Lithuanian deterrence strategy was aimed at convincing potential aggressors that Lithuania will not be able to occupy and control their country. Military occupation would require substantial costs, especially if one assumes that civilian resistance would last for decades. Informal study conducted by the Lithuanian Ministry of Defence in 1999 estimated that to sustain a corps of 40 thousand occupational troops in Lithuania would cost 1 bln USD per year, control of all Baltic States would be approximately $1.8 \mathrm{bln}$ USD. ${ }^{10}$ For potential aggressor to sustain such cost for many years could seem to be not an attracting

\footnotetext{
${ }^{9}$ Lithuanian Military Defence Strategy, (note 2), p.9-10.

${ }^{10}$ Atgrasinimo strategija II [Deterrence strategy II], Krašto apsaugos ministerija, 1999.
} 
alternative. Authors of nonofficial study suggested also considering effect of economic sanctions that would imply even higher costs for the potential aggressor.

In making their plans, Lithuanian military planners acted on the estimation that Lithuania and other Baltic states are important militarily only on the regional not on the global scale. They assumed that just for the sake of occupying the Baltic States no country would be willing to be involved into a bigger crises. Only under exceptional circumstances in the case of renewed East - West confrontation, could Lithuania become an object of primary importance. Lithuanian military planners rightly assumed that during military conflict in the region:

- Potential aggressor most likely would use only part of its resources, would seek limited objectives and would try to minimise costs of military actions; or

- Military conflict would be global, and actions of potential aggressor would be determined by the overall military balance, not by Lithuanian deterrence potential.

From this analysis Lithuanian military planners concluded that probability of second scenario is extremely low, therefore Lithuania must concentrate its efforts to deter aggression with limited objectives. In such a scenario the Lithuanian armed forces must be able to impose unacceptable costs and deny the potential aggressor the opportunity to control her territory. Defence requires fewer resources than offence; defender must possess at least one third of fighting power at any given point in the military theatre of actions ${ }^{11}$. Lithuanian armed forces were tasked to restrain enemy's freedom of action and deny him access to most populated areas. This would create time for total mobilisation and opportunities for reinforcement of regular forces.

Lithuanian military planners understood that a would-be regional adventurer may decide to win at tolerable cost, before an outside power can intervene effectively. And that it has, or will have, the grand-strategic assets to hold on to its winnings. In other words, it expects to win the war, and then to win a peace. The adventurer may be quite wrong in these believes, but that does not matter for deterrence ${ }^{12}$. In order to avoid such scenario Lithuania needs rapid reaction forces able to held potential aggressor and defend strategic objects and lines of communication.

The Lithuanian Armed Forces development plans corresponded to these calculations. In 1998 Lithuanian Ministry of Defence planned to increase the active duty personnel in the armed forces up to 23 thousand in 2008, and up to 48 thousand in the next decades. Lithuanian military strategy of 2000 declared that:

Regular Land Forces will include up to four combat brigades and one logistics brigade. One of the combat brigades will be prepared as a rapid reaction brigade. Each combat brigade of Regular Land Forces will usually be composed of three motorised or

\footnotetext{
${ }^{11}$ Encyclopeadia Britannica. "The Theory and Conduct of War. Conventional Strategy", http:/ /www.britannica.com/, 28022005.

${ }^{12}$ Gray C. "Deterrence and Regional Conflict: Hopes, Fallacies, and "Fixes", Comparative Strategy 17 (2), 1998, p.58.
} 
mechanised infantry battalions and support elements. The Logistics brigade will consist of transport, supply, maintenance and medical battalions. Combat brigades will comprise elements of combat support (engineers, communications, etc.) and the attached combat service support units (transport, supply, maintenance, medical, etc.) from the Logistics brigade. Combat brigades and battalions will have air defence and artillery capabilities ${ }^{13}$.

In addition Lithuania planned to prepare about 100 thousand active reservist that would be able, in case of war, to augment the regular units. Such sizable Lithuanian armed forces supplemented by the police, border guard, Riflemen's Union formations and also the local population would be able to wage successful guerrilla warfare. Lithuania also assumed that potential aggressors are typically not attracted by the promise of victory in a long guerrilla warfare too much is uncertain and potential costs are too uncontrollable. A decision to undertake military aggression usually requires a perception that an option for rapid success exists. Given that a long war is a gamble, full of uncertainties and unknown and unanticipated dangers, decision-makers will ordinarily avoid starting a war unless they believe a quick victory is assured ${ }^{14}$. Denial of ability to calculate cost is almost certain condition for deterrence to work. Lithuanian defence planners were seeking just that.

What Lithuanian strategists emphasised is the importance of denying potential aggressors the ability to achieve a quick victory and control flow of events. Lithuanian threatened potential aggressors with a long guerrilla warfare, which by definition diminishes ability to calculate and control costs and creates situation of unpredictability and anarchy. The role of the National Defence Volunteers (The Home Guard) was of utmost importance. Armed with light riffles volunteers were not able to fight on the modern battlefield but they were tasked with carrying out guerrilla actions. Lithuania hoped that tens of thousand volunteers would prevent aggressor from using her infrastructure, controlling transit roads and industrial facilities.

Lithuanian deterrence strategy based on the concept of total und unconditional defence contained many weaknesses. First of all in order to deter it is not enough just to have capabilities. If the deterrer with defensive capabilities fails to communicate its capabilities on which deterrence rests, the offender could behave as if these capabilities do not exist. The conventional deterrer must reveal critical information about its capabilities (armaments, mobilisation resources, personnel numbers and other information) while the potential aggressor does not. Such openness would expose Lithuanian defence plans and would allow aggressor to modify his plans accordingly. The defender is in a real dilemma: To deter, he must appear to be ex post superior, capable of executing his deterrent threats. But to really be ex post superior, he must keep most of his capabilities secret $^{15}$ ". The effectives of Lithuania's strategy was suffering from this weakness embedded in the logic of conventional deterrence.

${ }^{13}$ Lithuanian Military Defence Strategy, (note 2), p.20.

${ }^{14}$ Rhodes E. Review of Empirical Studies of Conventional Deterrence. Occasional Paper, Center for Global Security and Democracy, Rutgers University, 1999. http://www.ciaonet.org, 0106 2005.

${ }^{15}$ Ibid. 
Secondly, such strategy was very expensive. Total defence principle requires preparing several hundred of thousand well trained reservist and volunteers, ammunition and armament storages, state mobilisation system able to convert civilian resources to military needs. On paper Lithuanian preparation for total defence received adequate allocations from the state budged - in 1999 Lithuanian Parliament passed the Law promising from 2001 to allocate 2 percent of gross domestic product purely for defence purposes ${ }^{16}$. Ministry of Defence planned that in the following years defence budget would even reach 2.25 percent of gross domestic product. These plans have never been realised and defence budget never reached 1.5 percent. The Lithuanian total defence system always remained at the early stage of development and never came close to Finish, Swedish or Swiss model. Lithuanian mobilisation system has never been tested since legislative framework foresaw only total mobilisation in case of war and did not provide an opportunity to mobilise one district or municipality. Neither Lithuanian politicians nor potential aggressors really knew the real capabilities of the country to counter aggression.

Thirdly, membership in NATO and the EU provided Lithuanian with the opportunity to assure effective deterrence using a more reliable and powerful means. Lithuania quickly found out that the concept of total defence is not compatible with a new understanding of collective defence. From 1999 NATO's Strategic Concept broadened the understanding of collective defence by including preventive measures outside NATO's territory. In order to fight new threats NATO is developing well trained expeditionary forces able to implement preventive measures and fight conventional war in case of attack against NATO. If Lithuania were to prepare its Armed Forces solely for self defence, it would become free rider inside NATO, the country that is able to enjoy NATO's security guarantees but not able to provide capabilities for the Alliance.

Lithuania and other allies are not able at the same time to develop big territorial structures with huge amount of conscripts and to prepare themselves with the capabilities for the collective defence. Lithuania announced that priority will be given to capabilities that will strengthen collective defence. Lithuanian Armed Forces must be mobile and flexible, well trained, modern, deployable and sustainable. Guidance of the Minister of Defence for 2006 - 2011 clearly states that Lithuania will not invest into military units and capabilities designed for territorial defence that do not provide additional value to $\mathrm{NATO}^{17}$. New guidance changed the conceptual framework of Lithuanian deterrence strategy - denial elements are loosing importance and are being replaced by preventive deterrent measures.

\footnotetext{
${ }^{16}$ The Law on the Financing Strategy of the Lithuanian National Defence System], 14 January 1999, Nr. VIII-1028, http://www3.lrs.lt/cgi-bin/preps2?Condition1=71537\&Condition2=. ${ }_{17}$ Gudelines of the Minister of National Defence 2006 - 2011 m., Vilnius, KAM Leidybos ir informacinio aprūpinimo tarnyba, 2004, p.10
} 


\section{Military Capabilities Required for Extended Deterrence}

The Lithuanian deterrence strategy experienced significant changes after the latest round of NATO and EU enlargement. NATO membership expanded the whole notion of national military capabilities - now they include Allied forces. NATO and the EU have important economic, military and other tools that could be used against unfriendly countries or even non-state actors.

Major challenge for deterrence provided by NATO and EU come from unreliability embedded in the concept of providing deterrence to the third countries (extended deterrence), in this case for Lithuania. To convince to the potential aggressor that a weaker state will use its military force for self defence is difficult but possible. To convince a potential aggressor that a third country will use military force for the benefit of the third nation is even more difficult. NATO countries agreed that if security guarantees will be extended to the Baltic States they must be strong and reliable. Weak security guarantees for the Baltic States could discredit the whole Alliance and would rise doubts about its commitment in other parts of the world.

NATO has substantial advantage of military power in almost any part of the world but in the Baltic region this advantage is not so much obvious. Military strategist must always consider the worst case scenario - Russia becomes antagonistic to the West and threatens the Baltic States with military force. In 1997 according to plans of Russian General staff the Baltic States could be occupied during the first stages of renewed global confrontation ${ }^{18}$. In 1999 Russia started military reform of its armed forces with special attention given to the Ural and Western direction including Kaliningrad. Russia is creating smaller but more powerful and mobile military formations near the borders of NATO countries. In Kaliningrad two divisions were transformed into rapid reaction brigades. Similar tendencies could be observed in Belarus. Belarusian Armed Forces shrank in size but became more robust and effective. Major transformation started after exercises Neman 2001. Belarus was divided into two military districts "West" and "North West" with three rapid reaction brigades in each of them ${ }^{19}$. Therefore reliable NATO security guarantees meant ability of the Alliance to assure effective defence under any scenario and coalition.

Not surprisingly even in the beginning of 2002 most Western analysts were convinced that Lithuania will not be invited during the second round of NATO enlargement. For example, on 30 April 2002 the influential think-tank Stratfor published analysis called "Baltic States membership in NATO unlikely". Stratfor argued that the military situation in the region prevents NATO from moving into the Baltics:

Defending and reinforcing the region is difficult because of the region's broad front, limited depth and restricted lines of communication. In the event of war, the

\footnotetext{
${ }^{18}$ National Defense University "Strategic Assessment: Flashpoint and Force Structure", 1997, http://www.ndu.edu/inss/sa97/sa97ch2.html, 01062002.

${ }^{19}$ Полевой А. "В Белоруссии реформируют армию“" [Polevoj A. Belarus reforms her armed forces], Независимая Газета, 25 October 2001.
} 
Baltic States would need to be reinforced, as Russian forces would neutralize the Baltic States in their move to protect Kaliningrad and its port facilities. NATO would need to move reinforcements overland, because Kaliningrad would make air and sea re-supply difficult. The road networks, developed over years of Soviet rule, favour Moscow. Limited ability to reinforce the region would allow Russia to secure the Baltic States, leaving a large number of NATO troops waiting on the beach for rescue. ${ }^{20}$

According to the Stratfor view, because of these vulnerabilities, any NATO security guarantee would be little more than a piece of paper. At most, NATO could offer a strategic deterrent - placing the Baltic States under the U.S. nuclear umbrella - but it is doubtful that Russia would believe the United States' willingness to risk a nuclear confrontation over the Baltic States ${ }^{21}$.

The hypothetically worst case scenario was presented in greater detail at the study Strategic and Operational Implications of NATO Enlargement in the Baltic Region prepared by the Institute of Foreign Policy Analysis (IFPA). They concluded that "should a worst-case scenario play out, the operational requirements for NATO and U.S. forces are likely to be similar to those that they would need in order to respond to a major threat in another theatre, such as the Persian Gulf. These would include core war fighting capabilities such as strategic lift, rapid reaction forces, the ability to deliver massed air-to-ground strikes in the early stages of a conflict, air-toground surveillance, and special operations forces (SOF)." 22

According to the IFPA, the United States is likely to be the prime supplier of both the Allied air support and special operational forces units. The present capabilities the U.S. would allow fulfilling its commitments, but it is worth considering that the ability of the United States to respond could be taxed if U.S. forces were engaged elsewhere in another major operation. The main conclusion from the operational study on Baltic defence assumes, that "as long as Russia confines itself to conventional options, the prospects for successfully defending the Baltic States under worst-case scenarios are good. However, the defensive equation becomes complicated when the potential for Russian use of weapons of mass destruction is considered." 23

The IFPA assumes that a hostile regime willing to attack the Baltic States outright, in all likelihood, would not limit itself to conventional options. At the very least, the Alliance and Baltic defence planners should not rule out the prospect of Russian WMD employment simply because it would violate international norms or risk provoking a broader conflict.

In 2002 the issue of defensibility of the Baltic States was raised in official or academic circles. During official and unofficial discussions several basic models for Baltic defence come out. The first option could be labelled as "the Polish model". It is premised on the existence of a sufficient base of indigenous forces

${ }^{20}$ Strategic Forecasting Baltic States Membership in NATO Unlikely, Global Intelligence Update, 2704 2001, http://www.stratfor.com

${ }^{21}$ Stratfor, "Baltic States Membership in NATO Unlikely", 30 April 2001, http://www.stratfor.biz, 01092005 .

${ }^{22}$ Institute for Foreign Policy Analysis (IFPA) "Strategic and Operational Implications of NATO Enlargement in the Baltic Region", 2002, p.3.

${ }^{23}$ Ibid. 
that would be reinforced in a crisis from the outside. This model requires Lithuania to develop for or Allies to be ready to rapidly deploy, to Lithuania, a considerable quantity of conventional armaments (tanks, artillery, armoured combat vehicles, attack helicopters, fighters). In the second "technological" model, reinforcements would come from 'over the horizon'. They would be largely based on American air power and precision guided munitions. The third option is a hybrid model which rests upon the employment of modest reinforcements, but would also include "over the horizon" air strikes. In theory, there exists the deterrence by retaliation model. Attacks would be carried out against the aggressor's civilian and economic targets using weapons of mass destruction.

All options have a different level of support in the US and among their Allies. The deterrence by retaliation model draws least support among all nations and the Baltic States. The U.S. might prefer the "technological" model, assuming that financial costs associated with this model would be modest and the capabilities required already exist. The technological model is not acceptable for the Baltic States, because it rests solely upon political U.S. commitment and does not assure its physical presence in the region. European and NATO members would prefer the traditional "Polish" model. For Lithuania it would mean the creation of large territorial forces able to conduct large-scale operations inside the country, but barely able to participate in "out of area" NATO operations. Considering that NATO nations are moving towards small, mobile and rapidly deployable units, the territorial model of defence model does not seem to be a feasible model for the Baltic States.

The reality after NATO's enlargement reflects a compromise between the needs of the Baltic States and the capacities of the Allies. Such a compromise means that reinforcements would come from European NATO members and from the United States. The hybrid model guarantees that deterrence would include the elements of the inevitability of defence and retaliation. For Lithuania it means that deterrence would be highly enhanced by the physical presence of the NATO troops in the region. This presence will be manifested in the form of common initiatives, military training, exercises or even the temporary location of NATO troops. This explains why Lithuania in highly interested in preserving the NATO air policing mission in Zokniai airport as it strengthens deterrence for the whole Baltic region.

RAND study dispersed doubts about indefensibility of the Baltic region prior to NATO enlargement. The Study was further enhanced in 2004 under the title Assuring Access in Key Strategic Regions ${ }^{24}$. The Baltic scenario of this study analyses implications of a military conflict in the Baltic regions for U.S. commitments to this region and America's ability to provide extended deterrence for the Baltic States. The scenario involves a Russian attempt to employ military coercion to separate the three Baltic States from NATO. According to this scenario the continued expansion of NATO towards Russia's border in Northern, Central and Eastern Europe has led Russia to feel increasingly encircled and vul-

${ }^{24}$ Larson E.V., Eaton D., Elrickn P., etc. Assuring Access in Key Strategic Regions. Santa Monica: RAND, 2004, p.65-86. 
nerable. The scenario assumes that the catalyst for the crisis in the Baltic States was the failure of Estonia and Latvia to fully integrate their ethnic Russian populations.

According the scenario, ethnic Russians become increasingly hostile towards their governments, begin a protest campaign and to look toward Russia for support. As the crisis intensified, ethnic Russian extremists attacked government installations and provoked internal clashes. NATO, however, reacted strongly to Russia's threats against its three newest members. The scenario assumes that Russia and Belarus successfully continue their political and economic integration. Belarus was willing to provide at least limited support for Russia in a confrontation with NATO over the Baltic States ${ }^{25}$. Both sides deploy significant military resources to respond to this crisis:

The Russian CONOP has four basic themes. The first is that the Russian military needs at least 30 days to mobilize if it is to have a chance of successfully achieving its strategic goals. As a result, no offensive anti-access operations can be conducted during this period. The second is to isolate the Baltic States in order to prevent the timely introduction of NATO forces. The third is to rapidly overrun the Baltic States so as to present NATO with a fait accompli and strengthen the Russian position in post-conflict negotiations. The fourth theme is to prepare to repel a NATO counterattack should it become necessary to do so. Russian airborne troops will seize and hold a series of coastal enclaves as well as the capitals of Latvia and Estonia ${ }^{26}$.

The Russian strategic objective was to separate the United States from its key European NATO Allies: Germany, Belgium, and the Netherlands. Only by using information and psychological operations to create the proper conditions (or take advantage of existing conditions) could they exploit a strategic rift between the United States and its NATO Allies and Russia could hope to successfully implement a strategically meaningful anti-access strategy. In RAND's opinion it is difficult to foresee, circumstances under which European NATO countries, especially Poland, would be unwilling to give its full support for this Americansponsored operation. However Germany has a strong Green Party and well-organized and popularly supported peace movements that could be exploited by Russian. German infrastructure is of particular importance because the allied forces commander would face two primary access requirements to the Baltic States: securing the major highways and railroad lines across Germany and Poland and securing and protecting major Polish Air Posts of Debarkation.

Polish air bases would be essential to NATO and U.S. tactical air operations over the Baltics. The Air and Sea Port of Debarkation, highways, and railroads in the Netherlands, Belgium, and Germany would be indispensable to the reception of ground forces arriving from continental America and to the onward movement of both NATO ground forces. This requirement for full access in Europe is the most important one that NATO force commander would place on our major the Allies. According to RAND's assessment NATO would be able to guarantee access via the narrow corridor of southern Lithuania near the Polish border. If the Baltic States will be able to secure access to the key debarkation

25 Ibid.

${ }^{26}$ Larson E.V., Eaton D., Elrickn P., (note 25), p.69. 
infrastructure on their own territory, NATO would be able to defend them against the armed aggression.

From all the above mentioned Baltic defensibility studies, the conclusion could be drawn that NATO countries have enough military resources to defend the Baltic States. The RAND study emphasises that in case of regional conflict, the U.S. is able even without the support of NATO European Allies to defend the Baltic States. However support from Germany, the United Kingdom, Denmark and Poland would increase American will and abilities to act. The biggest challenge for extended deterrence would come from ability of the Alliance to persuade the potential aggressor that military force will be used to protect the Baltic States.

Therefore Lithuanian strategy must be aimed at preventing its Allies from becoming deterred by a potential aggressor to assist her in case of armed attack. During the regional conflict NATO European countries will become the object of harsh information and psychological operations. These operations would be aimed at discrediting the Baltic States and creating an unfavourable public opinion for participation in the conflict and assisting the Baltic States. Not the lack of military resources, but assuring psychological credibility, would constitute the biggest challenge for extended deterrence for the Baltic States.

\section{Psychological Credibility of Extended Deterrence}

Deterrence fails when the deterrer is unable to convince the potential aggressor about the fatal consequence of its behaviour. Lithuania together with her Allies may fail to deter potential aggressor if he thinks that Lithuania will not fight or will not fight very hard, or also if he thinks that war is unavoidable or he is indifferent to threats. Deterrence is not only a matter of absolute military capability but rather of political choice and the will to use military force.

Security guarantees from third nations is difficult to assure. History provides many examples when extended deterrence fails, e.g. British and French security guarantees did not deter Germany from attacking Poland in 1939. Extended nuclear deterrence is even more difficult to implement. For the U.S., the UK or France to prove to other nations that they are ready to risk nuclear holocaust for the sake of another country is almost impossible. Lithuanian military planners must always take into account the unreliability of nuclear deterrence.

Four major critical areas could be distinguished analysing psychological credibility of deterrence:

- The domestic political agenda may require political leaders of one or another state to invoke military measures, e.g. against Lithuania. Aggression may occur even if total loses will be greater when the results are sought. Political leaders of potential aggressor may feel that inaction may be even more painful alternative then a lost war, especially if the future of the ruling regime is at stake.

- Potential aggressors tend to focus on their own internal needs and tend 
to ignore external signals such as behaviour of the deterrer. Aggression is less a function of opportunity than it is of need ${ }^{27}$. Especially during crises potential aggressors are likely to neglect deterrer's will or ability to act.

- Leaders may psychologically resist hearing enormously painful news that they would lose a war - and that they must therefore abandon cherished goals or policies essential to their continued control of power. Psychological pressures to ignore warning signs will be particularly strong during periods of internal or external crisis. Such leaders are more difficult to deter.

- Bureaucratic organizations may have blinders imposed by their institutionalized cognitive framework - that is, their deeply-rooted conception of how the world works and, more specifically, what another war would look like. This may result in unmotivated biases in interpreting new information ${ }^{28}$. During crises growing pressure complicates rational decision making. For example the RAND study on the defensibility of the Baltic States assumed that the crises between the Baltic States and Russia were sparked by the Russian speaking minorities. In this highly emotional situation the Kremlin may disregard rational calculation and make emotional decisions.

The above mentioned weaknesses of the deterrence strategy suggest that military capabilities per say or security guarantees by the third nations alone cannot deter aggressions. Lithuanians must convince the leaders of neighbouring countries that the military force will be used under any circumstance and aggression could bring no benefits, just looses. This task theoretically could be accomplished even without military forces - by misleading the enemy with the wrong information and by other means showing capabilities that do not exist. This would be an extremely dangerous strategy in the area of global communications.

Lithuanian strategic documents show that Lithuanian defence planners are fully aware of credibility issues in the deterrence strategy. The Lithuanian National Security Strategy and Military Strategy, the Law on the Fundamentals of the National Security, oblige each and every citizen to resist any aggression. Refusal to resist may lead even to criminal prosecution. Such a strict legal provision is intended to convey a message to all neighbours that use of military force in case of aggression is inevitable. The Law on the Fundamentals of the National Security even stipulates that if because of aggression a senior command-level official cannot freely exercise its responsibilities or pass orders, lower-level officials (commanders) may perform defence functions independently"29. The decentralised decision making system assures that no potential aggressor would be able to subjugate the country by forcing senior leadership to surrender to political or military pressure.

Confidence and security building measures, frequent high level visits

\footnotetext{
${ }^{27}$ Lebow R. Between Peace and War. The Nature of International Crisis, Baltimore: Johns Hopkins University, 1981, p.274-277

${ }^{28}$ Rhodes E., (note 15).

${ }^{29}$ Lithuanian Military Defence Strategy, (note 2), p.16.
} 
strengthen deterrence by reducing misunderstanding and misinterpretation factor between political and military leaders of the opposing states. Tight and unofficial contacts with leaders of all neighbouring countries would create atmosphere of openness and transparency. Unfortunately such a strategy is difficult to apply to Lithuania's eastern neighbours for a simple factor of strict hierarchy and reticence. However, such strategy could work with non-governmental organisations and academic institutions. Their representatives must be supplied with information on Lithuanian defence policy towards their region.

Positive image of the state among the Allies and potential aggressors also effects deterrence. The more a country is conceived as strong, united, warlike, threatening or even revengeful, the better for deterrence. It is also important that the deterrer would not be perceived negatively among the population of wouldbe aggressor. Leaders could try to stabilise a regime by organising small and victorious campaign against a small and unpopular country. Lithuania is interested not to become a problem solving tool for the leaders of undemocratic regimes in her neighbourhood. Lithuania is not in a very pleasant situation - for example Russian public polls indicate that Russians perceive the Baltic States as the most hostile countries towards Russia. Latvia is perceived as a hostile country by 49 percent of Russians, Lithuania - by 42 percent, Estonia - by 32 percent (Georgia, the U.S. and Ukraine lag further behind). ${ }^{30}$ At the same time, 70.5 percent of Russian inhabitants believe that the annexation of the Baltic States was voluntary in $1940 .{ }^{31}$ The image of Lithuania in Belarus is better, although in recent years observers emphasise well orchestrated public relation campaign against NATO and the United States.

The psychological reliability of NATO security guarantees greatly benefits from an advanced fixed and planned commitments to the Baltic regions. Lithuanian political and military leaders are fully aware that additional guarantees from the third countries given in the midst of crises do not achieve the desired effect. For example Peter Karlsten, Peter Howell and Artis Allen in their empirical analysis of conventional deterrence found that "repositioning one's forces in conjunction with a threat may help one win the war if the target refuses to yield, but it has rarely been instrumental in bringing about the success of the threat itself... The widely accepted notion, that the repositioning of naval forces is an effective means of communicating national commitment appears without general merit ${ }^{32}$. Potential aggressors are likely to suffer from "motivated biases" in their evaluation of the deterrer's new signals and actions. Therefore NATO should more frequently demonstrate its commitments to the Baltic States by the increasing number of exercises and other military activities in the region. Even before becoming a member of NATO, Lithuania started to transform major air-

${ }^{30}$ The Levada Center, results available online: http://www.levada.ru/press/2005060100.html, 12092005

${ }^{31}$ Bashkirova \& Partners 'Were the Baltic States actually occupied?', 16 June 2005, results available online: http://www.bashkirova-partners.ru/eng/?m_plg=articles\&act=view\&id=91, 12092005.

${ }^{32}$ Rhodes E., (note 15). 
ports and seaport to accommodate NATO reinforcements in case of a crises. The host nation support procedures were checked in practice during the biggest military exercises in the Baltic States "Amber Hope" or by assuring support to NATO air policing mission in Šiauliai air base in the Northern Lithuania. This suggests that Lithuania understands the potential value not only of clear preexisting treaties and commitments, but also of forward military presence.

Reliability of extended deterrence is highly enhanced by the consistency and continuity of in advanced established security commitments. The George G. W. Bush speech in Vilnius became an ambivalent symbol of NATO security guarantees "Our alliance has made a solemn pledge of protection, and anyone who would choose Lithuania as an enemy has also made an enemy of the United States of America. In the face of aggression, the brave people of Lithuania, Latvia and Estonia will never again stand alone ${ }^{33}$.

Such a clear and unambiguous commitment sends a very clear message to all potential aggressors that might one day think of attacking Lithuania. American political leaders are fully aware of the extent of their commitment to the Baltic region. Even the big opponent of NATO enlargement, Ted Carpenter, emphasised in the Washington Post that this commitment given by Americans must be honoured - otherwise the global system of American alliances would become unstable and unreliable. ${ }^{34}$ Therefore the question "would America risk nuclear confrontation for the sake of Vilnius" should be rephrased "would America risk its global system of Alliances for the sake of confrontation in the Baltic region". Lithuania and her Allies must strive that the answer would be "no".

\section{Strengthening Extended Deterrence}

After membership in NATO, collective security guarantees became the basis for Lithuanian security policy. Lithuanian military strategy of 2004 proclaims that "the aim of deterrence is to convince the potential aggressor that it will face not only the forces of Lithuania, but also of its Allies and will experience great damages which will not be worth the sought result $t^{35}$ ".

An extension of extended deterrence to Lithuania changed the character of her deterrence strategy and effected the Lithuanian armed forces development plans. Total defence concepts disappeared from Lithuanian security and military strategy. Several key remnants from the total defence era, such civil resistance remains, but even they were adapted to the new environment. Membership in NATO also implied that Lithuania is determined to contribute to defence of its Allies. Lithuania is too small to provide substantial military capabilities to defence for example of Turkey but it must bear appropriate share of commitments

${ }^{33}$ Remarks to the Citizens of Vilnius by the President George W. Bush, November 23 2002, http://www.state.gov/p/eur/rls/rm/2002/15452.htm, 20050601.

${ }^{34}$ Carpenter Carpenter T. "Casting NATO Line Perilously Far to East", Washington Times, $2002 \mathrm{~m}$. sausio $12 \mathrm{~d}$.

${ }^{35}$ Lithuanian Military Strategy, (note 3), p.6-7. 
to the Alliance.

A shift from territorial to collective defence establishes new requirements for effective deterrence. NATO security guarantees strengthened Lithuanian security. At the same time, security guarantees by the third nations have several serious weaknesses that must be taken into account by Lithuanian military planners. For example, Lithuania instead of investing into preparations for guerrilla warfare is shifting resources to deployable and sustainable military units. This may send a wrong signal to potential aggressors that Lithuania is no longer planning to fight in a protracted asymmetrical conflict. The aim of this section is to offer concrete guidance on how to avoid possible misinterpretations and assure the reliability of extended deterrence.

\subsection{Intelligence and Early Warning Systems}

Intelligence and early warning systems contribute to deterrence by providing timely and accurate information on a potential aggressor's behaviour, actions of its leaders, or the status of its military forces. The decision to launch a military attack is not made in one day and even if it is taken preparations for military action could take even several years. For example a RAND study on defensibility of the Baltic States assumed that Russia needs at least 30 day to start military action in the region. An effective intelligence network would allow Lithuania and its Allies anticipate an aggression or show of force and take countermeasures before the crises occurs. Countermeasure could include deployment of NATO and EU assets, strengthening of crises management bodies, preparation of citizens for unexpected events, partial or even total mobilisation.

After becoming a member of NATO, Lithuanian capabilities to forecast behaviour of neighbouring countries increased substantially. Lithuanian intelligence bodies were connected to common NATO intelligence sharing system that provides ability to retrieve data of other Allies and present a Lithuanian analysis of events in the Baltic region. The Lithuanian air surveillance and control system was integrated into NATO air defence system that assures real time exchange of air picture over the whole region. These measures set the risk factor for unexpected contingencies to a minimum level in the region and provide enough breathing time to prepare countermeasures if they are needed.

Despite significant improvement in the intelligence gathering sector, Lithuanian academic and official institutions still possess some unimpressive analytical capabilities. Already for several year Lithuanians have tried at winning in NATO and the EU the reputation of "experts on the Eastern European issues". Such attempts have already brought some results in the foreign policy field but the Lithuanian ability to offer fresh perspectives on development in Ukraine, Belarus, Moldova or Georgia is staggering. Lithuania has no world wide known think tanks or universities. Vilnius University Institute of International Relations and Political Science and Lithuanian Military Academy only partially fill this vacuum. Lithuania, Latvia and Estonia have no academic institutions that 
specialises in defence sector.

In the future Lithuania must more heavily invest into analytical tools to forecast decisions of political leaders in the neighbouring countries, foresee their foreign policy towards Lithuania, understand their political motives and signals send to domestic and foreign audience. The Lithuanian ability to the understand logic of potential aggressors would increase their effectiveness of deterrence. This information via crises management system must be quickly channelled to appropriate bodies and lead to very concrete actions.

\subsection{Participation in International Operations}

Lithuanian participation in international operations increases the reliability of extended deterrence by raising moral costs of non-assistance in cases of an attack against Lithuania. The leaders of the United States, the United Kingdom and other countries would find it increasing difficult not to use political, economic and even military measures in the Baltic area as Lithuanian soldiers every day risk their lives for common interests in Iraq, Afghanistan and other parts of the world. Lithuanian armed forces have already proved their ability to participate in high intensity operations. Special operation forces three times so far have participated in operation Enduring Freedom. In 2005 Lithuania took a lead in establishment of Provincial Reconstruction Team in the province of Ghwor in Afghanistan. By taking this decision Lithuania, for the first time in her modern history, took a responsibility for the reconstruction and stability for this poor province of a distant country. One might expect that one day Lithuanians would find the bulk of their armed forces deployed somewhere in the Middle East or South Eastern Asia. In case of sudden military crises in the Baltic region Lithuania would completely rely on commitments of the Allies as the majority of its fighting power would be thousand miles away.

European countries use different models as to how to prepare military units for international operations. Finland and Russia send in international operations identify units in advance that were created just for this purpose, for example, peacekeeping battalions. This model allows countries to conduct the best possible training for future peacekeepers and select the right people for international missions but on other hand this creates a two tiered military - one for international, another for domestic use. Such a differentiation could create tensions among the military and decrease the unity of the armed forces. Another choice is to create a professional military for all imaginable missions. They professionally must serve anywhere they are sent. This guarantees that all armed forces are capable of generating military units for collective actions including collective defence. Such a model is more expensive but also more effective in collective defence organisations.

In Lithuania elements from both models can be found. According to the Guidelines of the Minister of National Defence: "upon the completion of current defence reform by 2014, Lithuania will seek to have at least $50 \%$ of its Land Forces structured, trained and equipped for deployed operations outside Lithu- 
ania and at least $10 \%$ planned for or undertaking sustained operations at any time $^{36 "}$ ". This objective provides a clear indication for orientation towards a more professional armed forces although legal system has not been adjusted yet. According to Lithuanian laws military personnel can be sent to international operations only on a volunteer basis unless it is collective defence operation. This means that deployed military unit would be supplemented by personnel from other units thus reducing its coherence.

The principle of voluntarism leads to challenges for the effectiveness of extended deterrence in NATO. The concept of extended deterrence requires Allies to send reinforcements to a country in danger, prior to the start of military actions. Such deployment most probably would not be an Article 5 operation and a principle of voluntarism would be applied. If NATO would request to deploy the Motorised Infantry Brigade "Iron Wolf", Lithuania would have to struggle to find adequately trained people to replace at least several hundred soldiers. Such legal restrictions limit Lithuanian capabilities in times of crises to render assistance and assure extended deterrence to her Allies.

\subsection{Host Nation Support}

Lithuanian ability to provide host nation support (HNS) to arriving NATO forces significantly contributes to effective deterrence. Lithuania so far has invested heavily into HNS capabilities but currently investments in this area are under strict review.

During the Cold War era NATO countries, except for the United Kingdom and the United States, planned to defend themselves on their own territory. For this purpose countries like Germany developed substantial HNS support capabilities. A country providing HNS was responsible for development of effective medical support, for communication network, road and railroad controls and other capabilities.

Already prior to their membership in NATO, Lithuania decided to follow an example of older Alliance members that have substantial HNS capabilities and made HNS support one of the key priorities. The Ministry of Defence looked at the civilian infrastructure that could be used for the military use, and tasked the National Defence Volunteers and Logistics command to provide respectively force protection and logistics support capabilities. Lithuanian applied this concept during the Baltic States largest military exercise called "Amber Hope" and for NATO air policing mission stationed in Zokniai airfield in the Northern Lithuania. These were small scale operations comparing to those if during a military crises should NATO decided to deploy to Lithuania several divisions or corps. Lithuanian defence planners are facing the dilemma whether to spend huge resources for such unlikely scenario or use them for other purposes like participation in international operations.

${ }^{36}$ Guidelines of the Minister of National Defence 2006-2011, Vilnius: Leidybos centras prie KAM, 2005. 
Consensus has not been reached so far as to the extent of HNS investments. On one hand this would allow to accommodate faster arriving NATO forces and provide logistical support. This factor was mentioned in the RAND study on the defensibility of the Baltic States. From another hand Lithuania must stop all investment into this expensive capability for the following reasons. Firstly, NATO is developing sustainable and deployable expeditionary forces that are able to operate in any geographical environment. For example, NATO Reaction Forces (NRF) can operate without any HNS all over the globe. If NATO decides to use NRF in Lithuania its requirements for HNS would be minimal. Secondly, NATO has huge advantage in military power over any potential enemies' therefore Lithuanian preparations for HNS would not change the balance. Thirdly, in case of military threat NATO most probably would use preventive actions. As unofficially one NATO official said "who told you that the Alliance will defend you on your own territory?" The Alliance has military capabilities to strike anywhere in the world even and operate even in unfriendly environment.

The conclusion could be dawn that Lithuanian investment increases reliability of deterrence but contributes less to its effectiveness comparing to participation in international operations or early warning capabilities. Lithuanian should continue investments into critical infrastructure facilities like Zokniai airfield or Klaipeda sea port but not invest into HNS capabilities that could be used only in large scale military conflict.

\subsection{Arms Control Mechanisms}

Arms control strengthens deterrence by allowing participating parties to observe and verify military equipment in neighbouring states. Participation in arms control regimes enables Lithuania to receive and verify information on the capabilities of her neighbours. An effective arms control regime diminishes security dilemma and the potential for an arms race in the Baltic region by eliminating military superiority of one state over her neighbours. Arms control is also important as a confidence and security building measure. However arms control regimes have many in-built weaknesses - established limitation could be avoided or inspections neglected.

Effective arms control regimes strengthen the reliability of deterrence. According to the logic of deterrence aggression could happen if one country feels that it is loosing advantage over another, its competitor. First of all, arms control regimes eliminates the element of surprise in development of military capabilities. Secondly, it creates balance of military power thus reducing to a minimum the possibility of participating countries to have the first strike capability. Arms control regimes and limitation of troops in the Baltic area provide additional guarantees to countries like Russia that in times of crises no huge military potential would be concentrated close to her borders.

Lithuania is a party of most arms control treaties. Already in 1993, Lithuania joined the Vienna Document on confidence and security building measu- 
res and exchange of military information. In the 1999 Istanbul Summit, Lithuania declared that it was considering the possibility of accession to the Conventional Forces in Europe (CFE) Treaty, provided that the accession terms were in Lithuania's national interests. In September 2002, the President of Lithuania in his statement before the United Nations General Assembly reaffirmed the intention to accede to the CFE Treaty after the adapted treaty comes into force and is open to all European democracies. In addition, in 2002, Lithuania applied for membership in the Open Skies Treaty which creates the regime for aerial observation $^{37}$. The Founding Act on Mutual Relations, Cooperation and Security between NATO and the Russian Federation signed in 1997 also applies to Lithuania. It clearly states that "The member States of NATO reiterate that they have no intention, no plan, and no reason to deploy nuclear weapons on the territory of new members, nor any need to change any aspect of NATO's nuclear posture or nuclear policy - and do not foresee any future need to do so"38.

The biggest challenge for Lithuania in the foreseeable future will be joining the CFE treaty. The adapted CFE Treaty signed just prior to the first round of NATO enlargement envisaged that any upward revision of the national ceiling of one party must be compensated by a corresponding lowering of the national ceiling on the same territorial category of one or more other parties. This provides the guarantee for Russia that no major conventional weapon system will be accumulated in her neighbourhood. Russia will seek that similar logic will be applied to of the Baltic States. According to Zdrizdaw Lachowski the national and territorial ceilings of the Baltic states would be consistent with the military sufficiency rule, on the one hand, and would take account of Russia's genuine security concerns, on the other. The Baltic national limits would be higher than the current holdings. The Baltic States would have only limited possibilities for permanently stationed foreign troops and armaments on their territory, but their territorial ceilings (higher than the national ones) would enable them to receive reinforcements and temporary deployments (up to an equivalent of two NATO divisions) ${ }^{39}$.

These limits would diminish the reliability of deterrence since they put limitations on the presence of the Alliance on the territory of the new members. The U.S. and its European Allies agreed to assure Russia that no substantial military force will be deployed in her neighbourhood. This is political prise of NATO enlargement process. On the other hand participation in the CFE Treaty would significantly benefit Lithuania through greater insight into Russian political and military activities. Lithuanian involvement into arms control regimes is considerable, albeit not a critical strategy to strengthen effectiveness of deterrence.

\footnotetext{
${ }^{37}$ Užsienio reikalu ministerija. "Lietuva Prisijungè prie Atviro Dangaus Sutarties".\{Ministry of Foreign Affaires "Lithuania joint Open Skies Treaty" 22 July 2002, http://www.urm.lt/ view.php?cat_id=3\&msg_id=1266, 01092003.

38 "Founding Act on Mutual Relations, Cooperation and Security between NATO and the Russian Federation", NATO, http://www.nato.int/docu/basictxt/fndact-a.htm, 01092003.

${ }^{39}$ Lachovski Z. The Adapted CFE Treaty and the Admission of the Baltic States to NATO. Stockholm International Peace Research Institute, 2002, p.10..
} 


\subsection{Development of Defence Capabilities}

NATO security guarantees and national defence capabilities for many years will remain the core of Lithuanian deterrence strategy. Lithuania as a small state cannot cope alone with scenarios that involve extensive use of military force. In the case of a large case aggression, Lithuanian armed forces will act as a part of multinational joint task forces. Lithuanian military strategy emphasise that:

The wartime concept of Lithuania rests on the assurance of all Allies to confront a potential aggression jointly. Lithuania will fulfil its commitments with a capability centred on a highly capable Reaction Brigade and its supporting units. This capability will be responsive to threats that arise at any time, with units that can deploy quickly to defend the country in conjunction with NATO reinforcements ${ }^{40}$.

After completion of military reform almost all Lithuanian armed forces units will be designed to be usable for international operations. Deployable military units will be modernised and re-equipped. They will constitute the core of Lithuanian defence potential. Still many shortages will remain. The long term plan for the development of Lithuanian armed forces acknowledges:

Although Lithuanian armed forces modernisation plans are highly valued among our Allies and Lithuania takes part in many international operations, Lithuanian Armed forces still is have only limited capabilities to sustain military units on the modern battlefield. As military technologies advances at a very rapid speed, in the future, Lithuanian armed forces could find themselves unable to operate together with her Allies ${ }^{41}$.

In 1999 Lithuanian started the Strategic Defence Review which established a new slimmer yet more capable force structure. A number of infantry brigades were reduced to one rapid reaction brigade; territorial units were transformed into smaller but deployable formations. Lithuania started to create expeditionary logistics capabilities, reformed training systems. Lithuania plans to launch, from 2007, a major modernisation effort giving priority to military units assigned to NATO or other EU operations.

In preparing modernisation plans, Lithuanian planners must take into consideration that recent military innovations favour the defence, which is important part of deterrence strategy. Extremely precise and comparatively simple guided weapons could be used to take on tanks and high-performance aircraft, the central actors in any offensive..$^{42}$ Acquisition of anti-offensive weapon systems greatly enhances defence and deterrence. New technologies highly strengthen defence against tanks or fighter aircraft, central figures in all offensive operation $^{43}$. Modern equipment even allows Lithuania to strike into potential

${ }^{40}$ Lithuanian Military Strategy, (note 3), p.10.

${ }^{41}$ National Defence System Long Term Development Plan, (note 9).

42 Encyclopeadia Britannica, (note 12).

${ }^{43}$ Ibidem. 
enemies' territory with conventional means. Lithuania in the long term perspective must consider procurement of similar systems. Lithuanian leaders must take into consideration that neighbouring countries are increasing their defence expenditure and their modernisation plans are extremely ambitious. Lithuania has to increase allocations for procurement of more sophisticated equipment; otherwise in the future she will be in danger and may rely exclusively on the security guarantees from the third nations without having anything to offer to her Allies.

\subsection{Economic Measures}

The reliability of deterrence strategy depends on ability of the detterer to impose economic costs to the aggressor. War means breaking economic relations with the target of aggression and its Allies; international sanctions may follow. In the interdependent world this implies huge costs to the war-prone states. In addition, breaking economic relations could seriously harm economic interests groups. Not surprisingly, the Independent Task Force in its report "U.S. Policy Toward North-eastern Europe" emphasised "whether or not NATO could defend the Baltic States in a strict military sense may be less important than making it clear that any effort by Russia to use force in the Baltics would prompt a strong response by NATO against highly valued Russian assets. This could serve to deter Russia from taking military action against the Baltic States" ${ }^{\prime 44}$.

In case of aggression against Lithuanian international sanctions would immediately follow. Sanctions could be of different nature - termination of loans, trade restriction, and freeze of capital or investment projects. Credibility of international sanctions would be fostered by deeper integration of Lithuania into common European market, big investment and communication projects. Joining of Euro zone and Shengen zone would further increase reliability of deterrence. The EU does not provide formal guarantees of defence albeit it is hard to imagine European countries closing their eyes in the case of aggression against one or more EU members.

The EU has the real power to influence political military decisions in other countries, especially Russia. EU countries account for over one half of all direct investment in Russia, and the EU is Russia's largest creditor. The EU is Russia's leading trading partner; 40 percent of Russia's foreign trade is with the $\mathrm{EU}$, and the figure rose to 50 percent with the enlargement of the EU. In contrast, trade with Russia accounts for only around 4 percent of the total foreign trade of the EU, and this level is only slightly higher after the enlargement of the EU. Russia is heavily dependent on the EU in economic terms, but the reverse is not true. The only exception is in the energy sector. Oil and gas supplies account for around 50 percent of total EU imports from Russia, and the EU demand is pro-

${ }^{44}$ Brzezinski Z., Larrabee F. "US Policy Towards Northeastern Europe", (Independent Task Forces Report), Council on Foreign Relations, 1999, http://www.cfr.org/content/publications/attachments/Northeastern_Europe.pdf, 28022005. 
jected to increase in the future, particularly in the case of natural gas (the EU oil market currently depends on Russia for approximately 20 percent of its supply, but the figure rises to approximately 45 percent for gas). In the enlarged EU, Europe's reliance on Russian fuels has increased since, with the exception of Slovenia, all the Eastern European candidate states are almost totally dependent (between 70 and 100 percent) on gas and oil supplies from Russia ${ }^{45}$. Thus in case of military conflict in the Baltic region the EU and Russia would suffer enormously.

Economical measures are important but not critical for reliable deterrence. First of all, they bring costs to the aggressor when decision to start aggression has already been made. In case of irrational aggressor their impact is even of less importance. Secondly, authoritarian rulers tend to disregard economic costs and allocate more attention to military dynamics. Establishment of authoritarian regimes close to Lithuania makes deterrence more difficult. One of the biggest challenges to the Lithuanian deterrence strategy would be strengthening of the unpredictable authoritarian political and military elites in the neighbouring countries. The ability to impose economic costs, although important, will not deter such elites. Readiness to fight will remain the main component of a reliable deterrence strategy.

\section{Conclusion}

Deterrence is the core element of Lithuanian security and military strategies. Its success ratio cannot be easily assessed mathematically, however, during the period after the declaration of independence Lithuania successfully resisted military and political pressure from outside powers to change its course towards integration into Euro-Atlantic structures. Furthermore, disagreements over NATO enlargement did not lead to the serious military build-up in the region. Lithuanian foreign policy remained focused on integration into NATO and the EU, preservation of American interest and participation in international efforts to build stability in other parts of the world. Russian and Belorussian politicians failed in their attempts to persuade Western countries that application of extended deterrence in the Baltic region is unreliable and unstable.

Before membership in NATO Lithuanian military strategy emphasised deterrence by denial. Lithuania had no capabilities to engage targets on an opponents' territory. Lithuania was able to deter other countries only denying the potential aggressor control of the state's territory and waging guerrilla warfare. In other words - Lithuanian strategy was to increase costs of occupation and military control. This strategy had several serious weaknesses. First of all, it

\footnotetext{
$\overline{45}$ Perovic J. “Coming Closer or Drifting Apart? EU-Russia Partnership and EU Enlargement in Eastern Europe“" Center for Security Studies, ETH Zurich, 2003, http://www.isn.ethz.ch/ pubs/ph/details.cfm?v21=61682\&lng=en\&id=6831, 2802 2005; Stratfor, "Russia Poised to Dominate European Energy“, October 11 2005, http://www.stratfor.biz, 01092003.
} 
allowed the potential aggressor to have information superiority. Secondly, Lithuania had no capacity to deny a fait accomply situation. Thirdly, costs of the military conflict would be unacceptable for future Lithuanian social and economic development.

After NATO membership, the Lithuanian deterrence strategy shifted its focus towards assurance of extended deterrence. In military terms this means creation of expeditionary capabilities for the Alliance and abolishment of territorial forces. Defence reforms allowed increasing Lithuanian commitments to its Allies; this in turn implied more active involvement of other NATO nations in the Baltic region. Reliability of deterrence was assured by clear and unambiguous security guarantees; however membership in the EU strengthened deterrence by integrating Lithuania more closely into European economic area.

In summary, the conclusion could be drawn that reliability of Lithuanian deterrence strategy is based on national and international means and procedures, membership in NATO and the EU. Deterrence could be further strengthened by portraying Lithuania in other NATO countries as reliable and strong partner, increasing its economic and financial integration in the EU, expanding participation in international outreach programmes or fostering other forms of military, economic and financial integration. These means increased costs for the Allianse of not acting in case of serious troubles in the Baltic region. But the most important item on the Lithuanian agenda is more intense efforts being made in potential aggressor's societies in trying to convince their leaders that Lithuanian is ready to fight any attempt to impose their will upon the Lithuanian government. This constitutes huge challenge for a small country that is surrounded by larger neighbours. Effective deterrence strategy requires united and well coordinated efforts from all governmental and non-governmental Lithuanian institutions. 